\title{
Ocorrência do mofo cinzento causado por Botrytis cinerea em grevílea
}

\author{
Álvaro Figueredo dos Santos ${ }^{1}$, Sandro Alex Rosa Alves ${ }^{1}$, Albino Grigolleti Júnior ${ }^{1}$ \& Dauri José Tessmann ${ }^{2}$ \\ ${ }^{1}$ Embrapa Florestas, 84311-000, Colombo, PR, Brasil; ${ }^{2}$ Departamento de Agronomia, Universidade Estadual de Maringá, \\ Maringá, PR, Brasil
}

Autor para correspondência: Álvaro F. dos Santos, e-mail: alvaro@cnpf.embrapa.br

\section{RESUMO}

O mofo cinzento, causado por Botrytis cinerea, foi observado atacando folhas e ramos de mudas de grevílea em um viveiro em Colombo, Estado do Paraná, Brasil. Este é o primeiro relato de mofo cinzento em G. robusta no mundo.

Palavras-chave: Etiologia, espécie florestal, Grevillea robusta.

\section{ABSTRACT}

Occurrence of gray mold caused by Botrytis cinerea in grevillea

Gray mold caused by Botrytis cinerea was observed attacking leaves and stem shoots of grevillea in a nursery at Colombo, Paraná State, Brazil. This is the first record of gray mold on G. robusta in the world.

Keywords: Etiology, forest species, Grevillea robusta.

Grevílea (Grevillea robusta A. Cunn.) é uma espécie florestal de origem australiana, que foi introduzida no Brasil no final do século XIX, no Estado de São Paulo, para sombreamento de cafezais. Atualmente, os principais usos dessa espécie incluem ornamentação, sombreamento de culturas agrícolas e pastagens, produção de serapilheira, quebra-ventos e mel. Nos últimos anos vem se destacando, experimentalmente, o uso da sua madeira para a fabricação de móveis (Santos \& Martins, 2002). Em julho de 2005, em um viveiro em Colombo PR, verificou-se o ataque a mudas de grevílea, por uma doença anteriormente desconhecida caracterizada por lesões necróticas nas folhas e ramos (Figura $1 \mathrm{~A}-\mathrm{B}$ ). Este trabalho teve o objetivo de elucidar a etiologia dessa doença.

Foram coletadas folhas e ramos infectados de mudas de grevílea e efetuado o isolamento do patógeno a estes associado. Este consistiu na retirada de fragmentos das amostras das folhas de grevílea com sintomas da doença (Figura 1B), procedendose a desinfestação em álcool $70 \%$ (30 s) e hipoclorito de sódio $0,5 \%$ (30 s). Os fragmentos foram depositados em placas de Petri com meio BDA e deixados em ambiente de laboratório, verificando-se, posteriormente, a formação de colônias acinzentadas (Figura 1C).

Nas observações em microscópio, o fungo apresentou micélio com hifas ramificadas, septadas, cor marrom acinzentado ou marrom oliváceo. Conidióforos longos, com 1,33-2,80 mm de comprimento e 10-13 $\mu \mathrm{m}$ de diâmetro, eretos, de cor marrom oliváceo, ramificados no ápice, com células conidiogênicas terminais, dilatadas, formando agregados de conídios em esterigmas curtos. Conídios elipsóides a obovóides, asseptados, com hilo protuberante, ligeiramente acinzentados, medindo $12,45 \times 5,55 \mu \mathrm{m}$ (média de 50 medições). As colônias ao atingirem a borda da placa de Petri, produziram escleródios escuros medindo 1,70-1,85 $\mathrm{mm}$ X 0,90-1,69 mm. As estruturas e as características das colônias são típicas do fungo Botrytis cinerea Pers. ex Fries (Figura 1 D-E) (Ellis, 1971).

Para comprovar a patogenicidade desse fungo, foram inoculadas folhas e ramos de mudas de grevílea, previamente feridos com agulha, com a deposição de discos de cultura do fungo em BDA com 7 mm de diâmetro, retirados de colônias com sete dias de idade. A testemunha consistiu em plantas de grevílea com ferimento, sobre as quais se depositou somente discos de BDA sem colônias fúngicas. As plantas inoculadas foram colocadas em condições de câmara úmida em casa de vegetação, até a avaliação.

Os primeiros sintomas foram observados aos sete dias após a inoculação das plantas, caracterizando-se pelo escurecimento da área inoculada e adjacências. Aos 15 dias já chamava atenção, nos sintomas do mofo cinzento, o abundante micélio aéreo de cor acinzentada que cobria totalmente as partes lesionadas das folhas. Nestas lesões, notou-se a presença de frutificações (conidióforos e conídios) nas faces abaxial e adaxial das folhas, facilmente observados em microscópio estereoscópico. Os sintomas e sinais foram semelhantes aos observados nas plantas infectadas naturalmente. As testemunhas não apresentaram sintomas. O fungo foi reisolado das folhas e ramos sintomáticos em BDA. As folhas sintomáticas foram herborizadas e depositadas no Museu Botânico Municipal, Curitiba PR, sob registro n 332781.

$B$. cinerea é parasita facultativo e apresenta vasta gama de hospedeiros no Brasil (Mendes et al., 1988) e em outros países (Farr et al., 2008). Na Austrália há um relato 


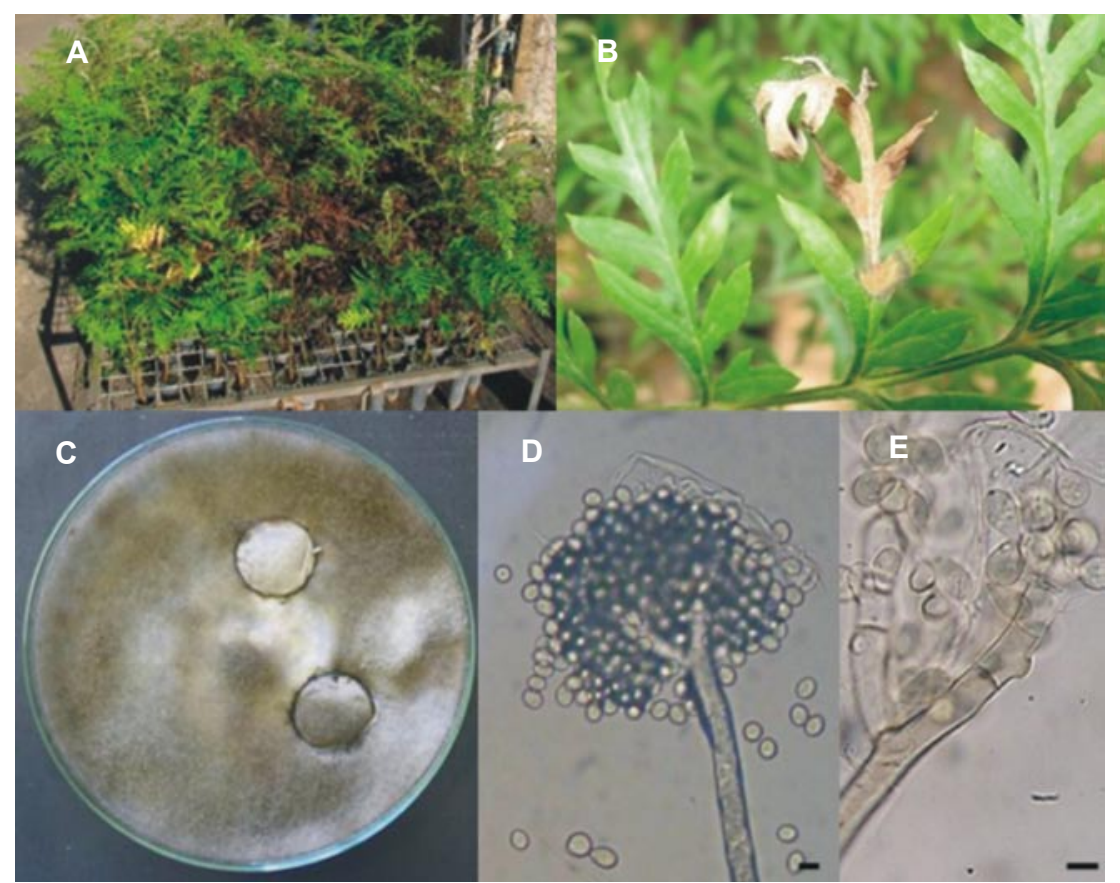

FIG. 1 - Mofo cinzento em grevílea: A. Bandeja com mudas atacadas; B. Lesões em folha; C. Aspecto da colônia em meio BDA; D. Ápice de conidóforo de Botrytis cinerea com grupo de conídios; E. Detalhe de ápice de conidióforo de Botrytis cinérea, com células conidiogênicas formando conídios. $($ Barra $=10 \mu \mathrm{m})$. anterior de um fungo associado com grevilea identificado apenas como Botrytis sp. (Simmonds, 1966). Este trabalho constitui-se no primeiro relato de $B$. cinerea como patógeno de G. robusta no mundo.

\section{REFERÊNCIAS BIBLIOGRÁFICAS}

Ellis MB (1971) Dematiaceous Hyphomycetes. Kew. Commonwealth Mycological Institute.
Farr DF, Rossman AY, Palm ME, McCray EB (2008) Fungal Databases, Systematic Mycology and Microbiology Laboratory, ARS, USDA. Access: June 20, 2008. http://nt.ars-grin.gov/ fungaldatabases/

Santos AF, Martins, EG (2002) Pragas e doenças. In: Martins EG, Medrado, MJS (Eds.) Cultivo da grevílea nas regiões sul e sudeste do Brasil. Sistema de Produção. Colombo PR. Embrapa Florestas.

Simmonds JH (1966) Host index of plants diseases in Queensland. Brisbane. Queensland Department of Primary Industries. 